\title{
Achieving Sustainable Development and Knowledge-Based Economy in Serbia
}

\author{
UDC: $330.341 .1(497.11)$ \\ 005.94 \\ DOI: 10.7595/management.fon.2015.0015
}

\begin{abstract}
Sustainable development and knowledge-based economy are the two concepts that are being conducted by the majority of countries in the world, including the EU member countries and the EU candidates. The aim of this paper is to analyse the progress in achieving sustainable development and knowledge-based economy in Serbia, a EU candidate country. A comparative analysis of conducting sustainable development and knowledge-based economy has been performed between Serbia and the EU(28). The focus is on economic aspects of these two concepts. The results differ. The goals that were initially set for achieving sustainable development and knowledge-based economy were either not reached or were hindered due to the global economic crisis and redirected towards solving more urgent economic issues. This is particularly noticeable in Serbia, which is carrying out economic reforms in order to achieve economic progress and meet the requirements for getting access to the EU.
\end{abstract}

Keywords: knowledge-based economy, sustainable development, Serbia, the EU

\section{Introduction}

Constant changes that result not only from scientific, technological and technical development, but also from modern ways of doing business, happen every day all around the world. Global market participants need to adapt their activities to the ongoing changes. Furthermore, each country tries to improve the level of its economic development to achieve a greater living standard and well-being. Economic development rests on certain factors that should increase the levels of production, employment, income, consumption, and other economic indicators. However, owing to global changes, a new concept was introduced in the 1980 s - the concept of sustainable development. The concept includes economic, social cultural and ecological components. Besides economic goals, the concept of sustainable development includes other goals as well, such as: poverty, education, health care, environmental protection, population migrations, urban overcrowding, social inclusion, etc. This concept has its focus on human development, i.e., equally developing all the spheres within a society. Economic development, along with environmental protection and conservation is the main purpose of sustainable development. In October 1987, The World Commission on Environment and Development (WCED), the Brundtland Commission in the report Our Common Future gave a definition of sustainable development. This definition has been most frequently quoted, and it states that "sustainable development is the ability to make development sustainable - to ensure that it meets the needs of the present without compromising the ability of future generations to meet their own needs".

Each country needs to increase its level of development depending on the available resources. The resources have to be used for achieving development, but as most of the resources are finite they should be sustained to provide for the needs of future generations. Today, many countries conduct the process of sustainable development along with the process of establishing knowledge-based economy. The two processes have to be harmonised in order to achieve some relevant changes and reforms. A country needs to adopt a national sustainable development strategy to be able to conduct the process of sustainable development. These are the basic research issues discussed within this paper. The aim of the paper is to assess the progress of sustainable development and knowledge-based economy processes in Serbia. 
The paper is organised as follows: section 2 provides a theoretical overview of sustainable development and knowledge-based economy concepts and their mutual interrelation. Sections 3 and 4 provide an overview of indicators for measurement of sustainable development and the comparative analysis of sustainable development and knowledge-based economy between Serbia and the EU(28). The final section summarises the conclusions.

\section{The Concepts of Sustainable Development and Knowledge-Based Economy}

In the times of global changes and integrations, new concepts are being established. Economic growth and development are based on various factors. Over the course of time, some new factors were introduced and consequently the theories of economic growth and development have been changed. Measuring the influences and contributions of certain factors to economic growth is based on various growth models. The models are used both to predict and estimate economic growth and to measure the contribution of each factor to the growth. Capital, labour and natural resources are the traditional factors that contribute to the growth and development of a country. Gradually, some new factors have been introduced: technology, human capital, knowledge and innovation. (Solow, 1956; Schumpeter, 1982; Romer,1986; Lucas, 1988; Jones, 1995; Barro, 1991; Rostow, 1960). According to the endogenous growth theory (Romer, 1994), economic growth can be achieved by investment in human capital, innovation (R\&D) and knowledge. Drucker (1993) argues that knowledge is the key factor for achieving economic growth in the knowledge society. Investing into knowledge brings about growth in productivity and efficiency of other factors in production. Furthermore, knowledge as a growth factor that includes environmental protection is a popular issue discussed in various research studies (Huggins and Izushi, 2007; Sabau 2010; Gorghiu and Petrescu, 2014). Environmental protection and natural resources conservation, on one hand, and achieving economic growth and development, on the other, have become a mutual goal of many countries worldwide as this is the best way to achieve sustainable growth and development. Such development is a long-lasting, comprehensive and synergetic process that affects all aspects of life on all its levels (locally, regionally and globally) (Kragulj, 2014).

In 2000, the EU set a goal to establish knowledge-based economy and obtain sustainable development. All the members, candidate and potential candidate countries are obliged to adjust their strategies to conform to the EU strategies and to converge towards the goals set by the EU.

\subsection{The Concept of Knowledge-Based Economy}

The new concept of economy has different terms - knowledge-based economy, knowledge economy, etc. Even though these terms are used like synonyms because knowledge is the key factor of development, there are some differences. The OECD defines "knowledge-based economies" as "economies which are directly based on the production, distribution and use of knowledge and information" (OECD, 1996). According to Chen and Dahlman (2005) knowledge economy is "one that utilizes where knowledge is acquired, created, disseminated and used effectively to enhance economic growth and development of knowledge". Powell and Shenllman (2004) define the knowledge economy "as production and services based on knowledge-intensive activities that contribute to an accelerated pace of technical and scientific advance, as well as rapid obsolescence". The EU has set a goal to become the most competitive and knowledge-based economy in the world. According to the set goal, development could be obtained by a triangle of knowledge, i.e., the integration of education, R\&D and innovation. There is a need for synergy, cooperation and coordination of knowledge, innovation and advanced technologies. New knowledge creates innovation, which has applications in manufacturing and service industries. Advanced technologies are a tool that enables a dynamic and efficient creation and application of new knowledge. Depending on the sector, knowledge is analyzed as: production (R\&D), transmission (education and training) and transfer (diffusion of knowledge and innovation). Further, there is tactic and explicit knowledge (Nonaka and Takeuchi, 1995). Explicit knowledge is a codified knowledge embodied or contained in a system or process. It is available and can be transferred. This knowledge is obtained by education and training. Implicit or tactic knowledge is based on the experience and intuition. It is personal in nature and hard to attain.

Knowledge-based economy is increasingly viewed as a continuous process of transformation of the economy towards activities and sectors based on knowledge (education, R\&D, ICT, media, art and information). Developed countries have already related their economies to knowledge. One solution to increase their out- 
put is to build a knowledge-based economy. This option can be used in countries where productivity and growth are less dependent on natural resources, and which have a certain quality of human capital. There are a few methodologies that examine the development of the KBE. The methodology of the World Bank uses the Knowledge Assessment Methodology (KAM). This methodology has two indicators: Knowledge economy Index (KEI) and Knowledge Index (KI). The European Union uses the so-called European Innovation Scoreboards and Lisbon 2000 Indicators. The WEF competitiveness index is one that measures competitiveness. Moreover, there are other indicators showing the development of the KBE: investments in R\&D, investments in highly educated capital (researchers and doctor degree holders), capacities and quality of educational system (expenses of education and learning throughout the whole life), e-government (procurement of new equipment and modernization of public services), labour productivity, use of informationcommunication technologies, etc. (Cook and Leydesdorff, 2006).

Establishing and development of knowledge-based economy cause the changes in the growth factors and increase competitiveness. The traditional growth and development resources are less and less contributing to the progress, while knowledge and innovation gain more and more importance. Competitiveness represents "the set of institutions, policies and factors that determine the level of productivity of a country" (The World Economic Forum Report 2014-2015) and leads towards economic growth and prosperity by increasing the level of productivity. The countries that possess human capital, but whose productivity and growth depend to a lesser degree on natural resources, invest in knowledge to improve their productivity factors. Investing into knowledge, innovation and new technology helps attain economic growth and development. Such tendency is present in the most developed economies throughout the world, those that invest heavily in research and development (Jednak and Kragulj, 2010). Economic activities and systems that directly establish creation, circulation and application of knowledge and information are essential for knowledge-based economy.

\section{Lisbon Strategy and Europe 2020}

Since 2000, various economic reforms have been carried out in the EU. The Lisbon Strategy (2000) was set out in 2000 to help the EU create knowledge-based economy and make it the most competitive economy in the world by the year 2010. The key component of the Lisbon Strategy is the development and improvement of knowledge by increasing investment in education and professional improvement, as well as scientific and technological research and innovation. However, since many goals had not been achieved, a mid-term review of the achieved goals and results of the Lisbon Strategy (2005) was conducted. According to the review, the goals were not achieved because they were too broadly defined and they were not harmonised among the member states in terms of coordination, responsibility and priorities. The goals were set again, but basically, they were not much different from the previous ones. Unfortunately, the reforms envisaged by the Lisbon Strategy were not carried out until 2010, mostly due to external factors such as economic crisis. Therefore, a new EU growth strategy was launched in 2010 - Europe 2020. The key target set by the EU growth strategy - Europe 2020 is to make the EU a smart, sustainable and inclusive economy that will raise the level of productivity, employment and social cohesion (European Commission, 2010). According to this strategy, the EU should exit from the crisis by a smart, sustainable and inclusive growth. A smart growth is actually economic development based on knowledge and innovation. Sustainable growth promotes better resource efficiency, greener and more competitive economy, while the inclusive growth provides full employment in the economy that influences both social and territorial cohesion. Within each of the priorities, i.e., growth, there are certain initiatives. The headline targets set by Europe 2020 are: 1) higher employment rate (20-60 year-olds) from $69 \%$ to $75 \%, 2$ ) increased investment in R\&D from $1.9 \%$ of the EU's GDP to 3\% GDP, 3) reduced energy consumption (carbon-dioxide and other greenhouse gas emissions should be decreased by $20 \%$ as compared to 1990 , while the share of renewable energy should increase by $20 \%$ in total consumption), 4) education and applied science ( $40 \%$ of people that completed tertiary instead of the current $30 \%$ ), 5) reduced number of people living below the poverty lines from 80 to 60 million (European Commission, 2010).

\subsection{The Concept of Sustainable Development}

Sustainable development is the goal set by many economies. The term sustainable development was first mentioned in the 1930s, and in 1987 in Rio, The World Commission on Environment and Development officially defined the term. This concept of development was differently accepted and understood by different 
countries, because their available resources were different (Rudawska et al., 2013). The concept connects present generations to the future ones, since sustainable development should meet the needs of the present without compromising the needs of future generations to meet their own needs (Kragulj, 2014). Finite natural resources should be used today to a degree where they can provide economic growth, but they should also be sustained for the future generations to improve their quality of life. Therefore, the main concepts of sustainable development are: the concept of need and the idea of limitations of our environmental resources' availability to meet our present and future needs (WCED, 1987). Goodland and Ledec (1987) state that ,...sustainable development implies using renewable natural resources in a manner that does not eliminate or degrade them, or otherwise diminish their usefulness for future generations." According to Solow (1991) sustainable development can be achieved if the spent non-renewable resources are compensated by the increased quantity and quality of physical and human capital. He also mentions that we cannot know the preferences and technology of future generations. Moreover, goods and services can be substituted by each other. The resources can also be substituted. Therefore, sustainable development is based on the sustainable possibilities for production. However, all the definitions agree that the existing natural resources must not decrease. If technology and population growth are observed, it is clear that technology increases output making capital more efficient, while population growth decreases the stock of capital, thus making sustainable development less feasible (Pearce and Atkinson, 1998). Efficient management of the available natural resources and an adequate use of knowledge may have positive effects on sustainable development. According to Al-Roubaie (2013) management and organisation of both physical and human resources is needed for sustainable development.

Sustainable development implies a convergence between the three main pillars: 1) economic development - includes economic sustainability, i.e., the possibility to maintain a certain level of economic production, 2) social equality - a state of affairs where a country indefinitely maintains a defined level of social well-being, while the gap between rich and poor social classes is being reduced, 3) environmental protection - the possibility to maintain a defined level of environmental quality and to conserve natural resources. Besides the above mentioned pillars, there are suggestions that two more should be added: cultural diversification pillar (Hawkes, 2001, UNESCO, 2002) and political-institutional pillar (Commission on Sustainable Development, 1995; Djekic and Hafner, 2013).

The concept of sustainable development is recognised as a prerequisite for the progress of humanity. It is explained by sustainable economic activity, ecological component of development and more efficient development. Sustainable economic activity prevents total exhaustion of natural resources. The resources should be conserved, so that future generations can also utilise them for production. Ecological component implies that humans are part of nature and the activities they do should not endanger nature. A more efficient economic growth is achieved by utilising resources in an optimal way by making a balance between input and output (Pesic, 2002).

\section{Economic Approaches to Sustainable Development}

Two economic approaches appear in research: neoclassical and ecological economics give different explanations for the concept of sustainable development. The neoclassical theory rests on the marginal analysis. The central position belongs to a rational individual that tries to maximise his or her utility and preferences by interacting with the others through the market. Neoclassical economics focuses on prices, output and income distributions that are determined by supply and demand (Henning, 2008). According to this market theory, markets automatically assess austerity through price system. Although this school recognises the importance of developed markets, institutions and free trade for achieving economic growth, it does not recognise the importance of natural resources and sustainable development (Henning, 2008). Neoclassicists believe that sustainable development can be achieved by never-ending economic growth, since the society wants to have a never-ending well-being. They admit that natural resources are finite, but they do not see the reason why this is considered to be a limiting factor for achieving economic growth. They explain it by the fact that a decrease in natural capital can be compensated by increasing the capital produced by the society (Vivien, 2008). They see scientific technological progress as the crucial factor of economic progress.

All until recently, ecology was not considered important for making a success. The sources of economic success were created by cutting ecological costs. Ecological economics examines the relationship between economic and ecological systems with an aim to maintain ecological-economic system, i.e., a long-lasting, economically efficient, yet ecologically acceptable and ethically legitimate economy (Pokrajac, 2009). Such 
economy improves the economic theory by integrating natural systems, human values, health and well-being. It connects human and natural systems by choosing efficient policies that enable ecological sustainability, balanced resource distribution and efficient allocation of meagre resources. Ecological economics states that economic growth cannot exist without destroying natural resources and the environment, so the cost must include externalities, i.e., the expenditures such as: the cost of the damaged resources and natural systems, human health and well-being compromised by pollution. This is the only way to achieve sustainability, i.e., sustainable development. According to Romeriro (2012) "sustainable development must be economically sustainable (or efficient), socially desirable (or inclusive) and ecologically prudent (or balanced)".

\subsection{The Interrelation between Knowledge-Based Economy and Sustainable Development}

Knowledge-based economy (KBE) and sustainable development (SD) are set as goals by many economies worldwide. Such concepts connect economic, social and environmental aspects. Certain studies have shown that there is a connection between the two concepts. Knowledge-based economy can promote sustainable development through innovation sustained by economic growth. Knowledge-based economy is "based on production, distribution and use of knowledge and information" (OECD,1996). Research generates knowledge that in return generates innovation, which contributes to better competitiveness that brings about better economic performances. The integration of science, i.e., research and development, education, and IT is becoming a more and more important factor of development. Sustainable development should create a balance between economic growth and environmental protection. By applying knowledge-based economy factors knowledge, information and new technology, it is possible to utilise natural resources in a more efficient way and protect the environment without compromising economic growth. One of the Europe 2020 targets is achieving sustainable growth. According to Vivien (2008), sustainable growth is a necessary and sufficient condition for achieving sustainable development. Sabau (2010) claims that the complex of life-sustaining aggregate consists of economy, society and environmental protection, and that they are preconditioned by time, space and objective limits. He uses these dimensions as a basis to more broadly explain knowledgebased economy and sustainable development and the connection between them. Sabau explains that these two concepts have intangible dimensions that show the complementarity of the concepts.

According to Lapinskiene (2011), economic growth is important for achieving sustainable development. The research confirms that there is a connection between competitiveness and sustainability indicators and that maintaining economic growth improves sustainability in developing countries. Increased labour productivity is a competitiveness factor both on a national level and on the level of sustainable economic growth (Balu and Mladen, 1995). Melinkas (2010) claims that the establishing of knowledge-based society and knowledge economy is connected to sustainable development in the sense that the observation of attitudes and goals of sustainable development is a precondition for developing a knowledge-based society and knowledge economy. The countries that have an innovation system, human resource development, ICT infrastructure and business environment, also have sustainable economic growth (Piech, 2004). The Lisbon Strategy and Europe 2020 that set their goals and targets to increase competitiveness and build knowledge-based economy are mostly focused on economic growth and creating new jobs, while the EU Sustainable Development Strategy has its focus on social and environmental issues. The strategies are mutually complementary in terms of creating sustainable development in the EU, although with different emphases. The Lisbon Strategy and Europe 2020 try to achieve sustainable development by increasing competitiveness, economic growth and employment. The EU Sustainable Development Strategy sees economic development as a possibility to achieve sustainable development. Of utter importance for the EU Sustainable Development Strategy are the quality of life, inter and intra generational inheritance and the cohesion of all policies. (Sterure and Berger, 2010). According to The National Strategy for Sustainable Development Serbia (2008), one of the sustainable development pillars is knowledge-based economy, along with two other pillars - economic and social issues and environmental protection.

\section{Overview of Indicators for Measurement of Sustainable Development}

Sustainable development indicators have been developed by international organisations, both in the EU and globally. However, there is no unique indicator to measure the progress of sustainable development. The UN have their own methodology for sustainable development observation and measurement. Millennium development goals are incorporated into the UN sustainable development indicators. In 2006, the Commission 
on Sustainable Development (CSD) revised the indicators. There is a core set of 50 indicators that include 96 indicators of sustainable development. The indicators have been organised into CSD indicator themes: poverty; governance; health; education; demographics; natural hazards; atmosphere; land; oceans, seas and coasts; freshwater; biodiversity; economic development; global economic partnership; and consumption and production patterns.

The EU has developed a set of indicators that measure the levels of sustainable development of its members. They have been organised into ten main themes that cover more than one hundred indicators, twelve of which have been chosen as the headline indicators (Eurostat, 2015). The main themes are: socio-economic development, sustainable consumption and production, social inclusion, demographic changes, public health, climate change and energy, sustainable transport, natural resources, global partnership and good governance. Sustainable development indicators provide an overview of conducting sustainable development policies by answering the key questions: what is the quality of life, how are the resources allocated and how equitably, are they utilised efficiently, what is the condition of the resources and are there any consequences to the environment?

The National Strategy for Sustainable Development Serbia conformed both to the UN indicators and to the EU Sustainable Strategy. Serbia is the EU candidate country and for that reason the EU methodology will be used for the analysis of knowledge-based economy, competitiveness and sustainable development. Since not all the data about Serbia are provided by Eurostat, only the indicators covering the field of socioeconomic development will be presented. The indicators were chosen to cover the progress of knowledge-based economy, namely, whether the targets and sustainable development indicators of Europe 2020 have been achieved in accordance with the goals of the EU Sustainable Development Strategy.

\section{Discussion of Findings Based on the Indictors}

Serbia is carrying out economic reforms and policies that will help it achieve economic progress. Furthermore, Serbia is adjusting its policy to meet the EU policies in order to become a full EU member. Since 2000 , when the process of transition started, Serbia has recorded positive results in conducting economic and other reforms. However, due to the economic crisis, the progress slowed down, but in the post-crisis period, positive results have been recorded again. The reforms include the establishing of knowledge-based economy and sustainable development. The poor KBE establishment and implementation of sustainable development was the result of economic conditions in Serbia. Implementation of activities for achieving the sustainable development and KBE are defined by national documents. Sustainable Development Strategy of Serbia (2008) is compliant with the EU Sustainable Development Strategy, the Lisbon Strategy, the Millennium Development Goals UN, the National Millennium Development Goals of development in Republic of Serbia and other national strategies and documents. The strategy is based on three pillars: knowledgebased economy, social issues and environmental protection. The Strategy`s key pillar is knowledge-based economy. Education ensures the human capital that will apply knowledge towards economic development in the future period. National priorities are: 1) the EU membership; 2) development of competitive market economy and sustainable growth; 3) development of human resources and employment increase; 4) infrastructure development and balanced regional development and 5) protection and improvement of the environment and rational use of natural resources. The implementation of sustainable development in Serbia does not go fast. The most intense periods of strategy implementation were 2002-2003 and 2009-2011. Of the total planned, activities were realized mainly in the area of KBE, then in social development and least in the area of environmental protection. Economic reforms were implemented which influence the fulfilled aims of the economic pillar, i.e., knowledge-based economy.

Sustainable development data for Serbia in Eurostat are only available for socio-economic theme and sustainable consumption and production. Figures 1 and 2 present the two themes with their main indicators: Real GDP per capita and Resource productivity for the EU(28) and for Serbia. 


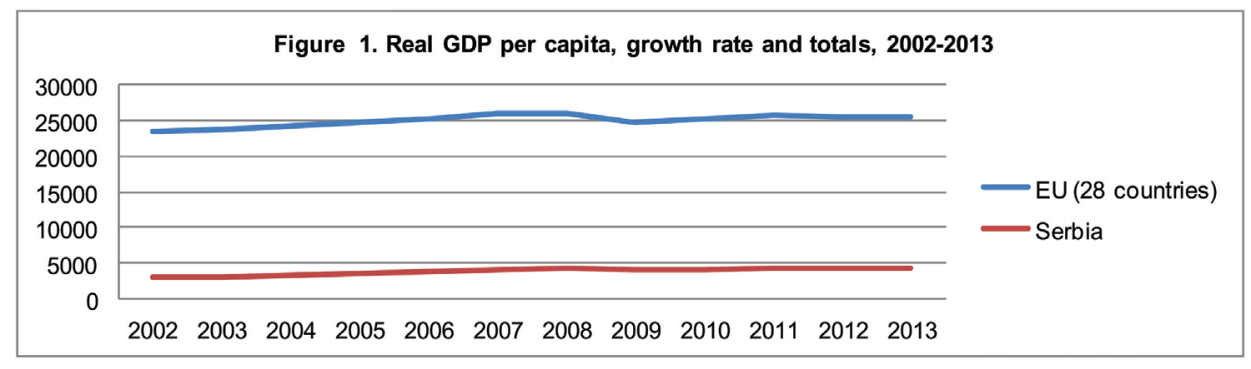

Source: Eurostat

In the observed period, the EU real GDP per capita ranged from $€ 23500$ (2002) to $€ 25500$ (2013). After a drop in 2008, the EU has kept flat GDP per capita. The countries with the highest GDP per capita are also the countries with the largest population (Germany, UK, Spain, and France). Apart from them, the countries with the highest GDP per capita are Luxembourg and the Netherlands (30\% above the EU(28) average). The reason for the growing GDP per capita in these countries lies in the fact that the Netherlands have legalised coffee shops with drugs and prostitution as well, while Luxembourg employs a great number of foreign residents. During the economic crisis the GDP per capita decreased. However, since 2010 onwards, a growth of economic activity has been recorded. In the period 2002-2013 Serbia had a trend similar to the EU(28), but on a lower level. In the pre-crisis period Serbia had an economic growth and GDP per capita rise due to economic reforms, high capital inflows, credit expansion, financial and trade integration with the EU. The model of economic growth was based on the domestic demand, foreign funds and imports. Until 2008, economic growth was obtained. However, with the global crisis and change of the model of economic growth, the GDP per capita started to decrease. The new model was based on the export and investment oriented growth. Export and foreign capital inflows started to fall during the economic crisis reflecting a drop in economic growth. Furthermore, tight fiscal policy, inadequate infrastructure and low productivity had a negative influence on the economic growth. Serbia recorded a drop in employment that exceeded the drop in GDP per capita. The GDP per capita ranged from $€ 2900$ to $€ 4300$. Serbian GDP per capita is about $60 \%$ below the EU(28) average. In 2013, unemployment in the EU (28) was 10.9\%, while in Serbia it was about $24 \%$. Restructuring, privatisation, inflexible labour market, underdeveloped private sector, decreases in economic activities during economic crisis caused high unemployment in Serbia.

Along with the increased income and standard of living, consumption also increases, influencing the increased utilisation of natural resources. In order to observe the connection between economic growth and utilisation of natural resources a resource productivity indicator is used. Better resource productivity influences better environmental protection and increased competitiveness.

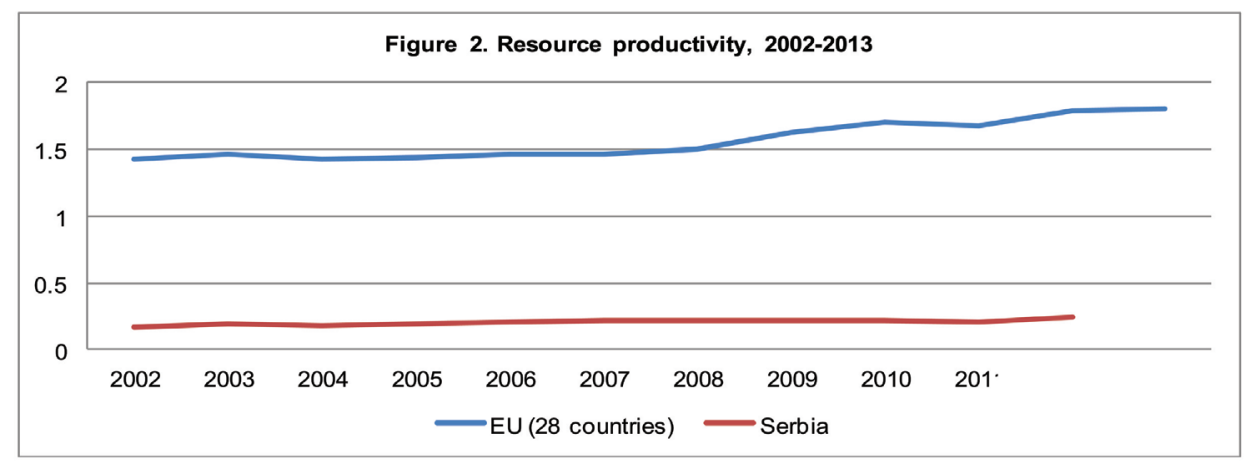

Source: Eurostat

Figure 2 shows that in the observed period 2002-2013, the EU generated more and more income from its domestic material consumption. It was particularly noticeable after 2008. The UK and Luxembourg are the EU member states that are the most resource-productive, while Romania and Bulgaria are ranked the lowest within this indicator. Serbia, like Romania, has low resource productivity. The differences in resource productivity are determined by structure of economy (basic industry vs. hi-tech manufacturing), share of service sector, the scale of consumption, the main source of energy and level of construction activities. The 
difference in the structure of the economies is the reason why the EU has so highly generated income in regard to its domestic material consumption (€1.43/kg to $€ 1.81 / \mathrm{kg}$ ) as compared to Serbia. The EU is a welldeveloped economy where the dominant sector is the service sector that generates most of GDP with low raw material consumption. During the observed period, Serbia recorded a slight growth of this indicator $(€$ $0.19 / \mathrm{kg}$ to $€ 0.24 / \mathrm{kg}$ ). During the period $2001-2011$ Serbian economy generated higher amount of GDP by using one unit of material. Resource productivity increased, while material intensity decreased. This means that less materials in $\mathrm{kg}$ was needed to produce one million dinars of GDP. Despite the growth in recourse usage, resource productivity had averagely risen by $1.9 \%$ per year. This is the result of a larger increase in GDP (3.3\%) than in Domestic Material Consumption (1.4\%). Serbia has obtained Sustainable Development aim decoupling. Even so, in 2013 resource productivity decreased by 5,6 \% compared to 2012 . The material consumption grew faster than gross domestic product (Statistical Office of the Republic of Serbia, 2013).

The total $R \& D$ expenditure is the indicator used to measure innovation. It shows the level of investment that participates in generating new knowledge. Figure 3 presents this indicator for the $E U(28)$ and Serbia, respectively.

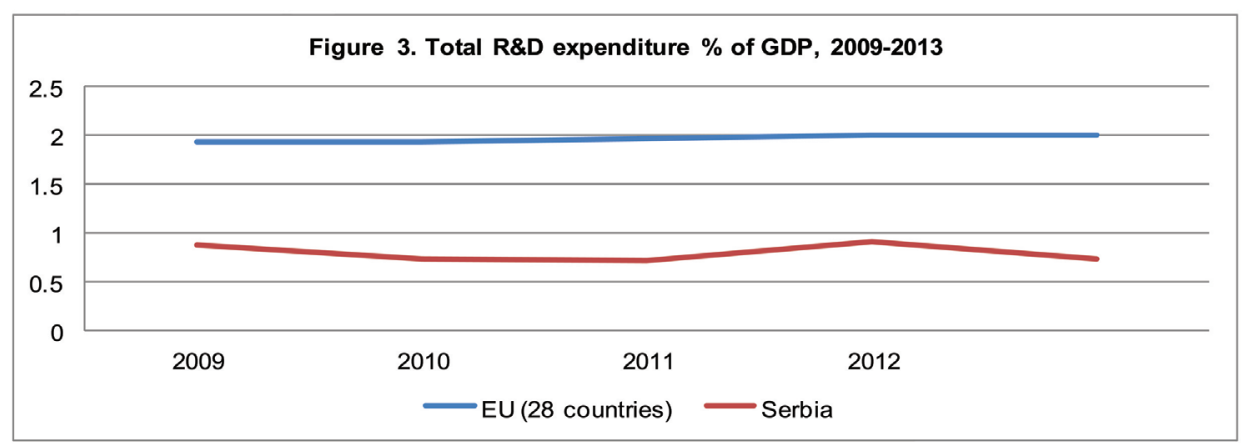

Source: Eurostat

In the period 2009-2013, the total R\&D expenditure was growing. Yet, it has to grow more for the target of $3 \%$ of GDP to be achieved. Serbia has insufficient investments in education, human capital, and R \& D. Therefore, Serbia has an insufficient number of highly educated people, inadequate qualification and skilled labour force, and underdeveloped educational and R \& D infrastructure. Additional problems for developing the higher education and $R \& D$ are: 1) low interest of the population in higher education; 2 ) low demand for innovation in the economy; 3) poor cooperation between business and universities, and between the universities and institutes; 4) low rate of the participation of researchers in the total number of employees - approximately $0.5 \%$ (in the EU it is $1.5 \%$ ); 5 ) the largest number of researchers employed in private companies $(51 \%)$, then in higher education $(35 \%)$ and institutes $(14 \%) ; 6)$ number of registered and protected patents is small - 53 patents per million inhabitants in Serbia (in the EU this number is 230), and the highest percentage of the patents are by individuals and not by organizations (Guide through the Europe 2020 Strategy / Vodic kroz strategiju Evropa 2020). In the period 2009-2013 the indicator was about 2\% of GDP in the EU(28). Serbia invests much less in R\&D than the EU; investment is below $1 \%$ of GDP. In Serbia, the largest share, $0.9 \%$ of GDP, has been allocated to education, while a smaller part to the R \& D, particularly for scientific research. About $90 \%$ of these allocations are for the salaries of employees in this sector, while a smaller part is directed to investments. In the EU the private sector share of R\&D amounts to about $63 \%$, while it is about $25 \%$ in Serbia. (ERAWATCH, 2013). In Serbia both private and public investments in R\&D have remained on a very low level, while the number of researchers is getting smaller and smaller. There seems to be no particular need to connect research to business and there is also a lack of integration into global knowledge networks. However, certain improvements have been made in R\&D and innovation, but Serbia still needs to meet many challenges in order to fully achieve the set targets. Serbia needs to invest more into R\&D, innovation and knowledge in order to bridge the technological and economic gap that exists between Serbia and the EU. In addition, these investments will contribute to the development of the knowledge-based economy which would build a Serbian competitive advantage in the international market.

The EU indicators of the socio-economic development theme during the period 2002-2013 varied. Some areas recorded progress, while others did not. It is characteristic of these indicators that during an economic crisis all the economic activities slow down. Investments, labour productivity and energy consump- 
tion decrease, while R\&D expenditure increases and there is also the unemployment issue. Sustainable development decreases during the economic crisis, but there is always progress in the post-crisis period. This is characteristic of the EU. It is also typical of Serbia, but on a lower level. According the Report on the Progress in Realisation of Sustainable Development National Strategy for the period 2009-2017 (2009) Serbia achieved some positive results, but there are still many problems to be solved. Serbia needs to reduce its fiscal deficit by increasing austerity measures, enable growth based on a new development model and provide funds to finance it. Although financial resources were considered to be a dominant factor of growth, according to various analyses, human resources are considered to be the most competitive factor of development. A balance needs to be reached between current expenditure and production in order to decrease the growing number of obligations that are being created by contemporary generations, which the future generations will have to fulfill. As regards environmental issues, regulations were adopted and conformed to the EU regulations: building environmental infrastructure, modernising the system of economic instruments for rational use of natural resources, natural resources conservation and establishing the necessary institutions.

The targets of knowledge-based economy that were made by the Lisbon Strategy and continued with Europe 2020 were not achieved due to the effects of the economic crisis. If we observe the goals directed towards increased growth, employment and competitiveness, there are different results. The EU achieved quite positive results in employment with $68.4 \%$ of the population (2013) (target $75 \%$ ) and R\&D investments with $2.02 \%$ of GDP (2013) (target 3\%). Poverty still remains the greatest issue. Positive results have been achieved in education. Education increases productivity, innovation and competitiveness. A smart and sustainable R\&D growth generates new knowledge and innovation, and along with an efficient use of natural resources leads towards better competitiveness. In order to improve the conditions induced by the economic crisis, the EU underwent fiscal consolidation and banking system restructuring to regain trust. The competitiveness was pushed into the background during that period. However, when the fiscal situation improved, the EU got back to its primary goal to achieve competitiveness by increasing productivity, employment and progress. The Europe 2020 Competitiveness Index (WEF, 2014) uses a 1-7 scale. In 2014, the $\mathrm{EU}(28)$ scored 4.56. If compared to the most developed countries in the world, the EU(28) lags behind.

The difficult macroeconomic situation in Serbia prevents the implementation of the Sustainable development strategy. Slow progress of structural reforms, decrease in foreign capital inflows, low national savings, investment orientation towards the primary sector, not towards infrastructure, R\&D, education and other sectors based on knowledge, have led to rise in unemployment and low productivity and competitiveness. According to the Global Competitiveness Index Serbia is ranked 94th out of 144 countries. Obstacles for competitiveness improving and achieving economic growth are: institutional factors (excessive state regulation and an inadequate legal system), the inefficiency of the market of goods, business sophistication, negative credit rating and low national savings. Serbia's goal is to obtain a better business environment and increase a demand for domestic products for achieving economic growth. Based on the Europe 2020 WEF Competitiveness Index (The Europe 2020 Competitiveness Report, 2014) Serbia scored 3.46 (scale is from 1 to 7). In order to achieve a better rank and to increase competitiveness Serbia needs to undergo reforms first by establishing institutional capacities in the country, and then by adopting certain policies and development factors. This is the way to increase productivity and employment that will bring about higher competitiveness. Government efforts should be focused on the improvement of institutional capacities, business environment, digital agenda, and education and training. Also, Serbia should address problems, i.e., constrains such as inefficient government bureaucracy, access to financing, corruption, policy instability and government instability (WEF Europe 2020 Competitiveness Report, 2014). Furthermore, the KBE is achieved at a modest growth rate. The KEI and KI show that Serbia is ranked 49th out of 146 countries. Serbia has highest results in ICT that are considered to be one of the factors that can influence economic growth. A low employment rate of 45\% (2013), low allocations in R\&D around 1\% of GDP (2013), low productivity, increased poverty, high public debt (around $70 \%$ of GDP, 2014), and fiscal consolidation slow down the achievement of economic development. Serbia needs to continue carrying out the reforms in order to achieve sustainable development and establish knowledge-based economy. In comparison with the EU(28) that itself did not achieve its goals, Serbia is considerably below the EU(28) average and below, or at the same level as the neighbouring countries, Romania and Bulgaria, depending on the indicator. 
Achieving economic growth, increased productivity and employment, social cohesion and reduced pressure on natural resources (namely, the environment) is the aim of both the EU and Serbia. As a EU candidate member, Serbia is trying to adjust its strategies and policies to meet the EU regulations. Along with carrying out the process of sustainable development, Serbia is trying to increase its growth and employment. However, obtaining sustainable development and establishing knowledge-based economy have been hindered, not only because the focus was shifted towards solving internal economic issues, but also because of the global economic crisis. Serbia needs fiscal consolidation, structural reforms, labour market reforms, increased investment in $R \& D$, innovation and knowledge. Yet, certain positive results have been achieved in reaching the goals of these two processes, but not with equal success. Development of knowledge-based economy is not the same in Serbia and in the EU, since they do not have the same resources and levels of knowledge. The main goal of Serbian development is carrying out economic reforms. The EU adopted the Sustainable Development Strategy and Europe 2020, but due to the global economic crisis, it redirected the goals of these strategies towards solving fiscal, monetary and other economic issues. In the post-crisis period the EU is on its way to achieve the strategic goals for sustainable development and knowledge-based economy, while Serbia primarily needs to solve its economic issues, trying at the same time to carry out the process of sustainable development and establish knowledge-based economy.

\section{REFERENCES}

[1] Al-Roubaie, A. (2013). Building knowledge capacity for sustainable development in the Arab world. International Journal of Innovation and Knowledge Management in Middle East \& North Africa. 2 (1).

[2] Balu, M.E. \& Mladen, L. (1995). Labour Productivity as a Factor of the Economics Sustainable Development. Commission on Sustainable Development, Report on the 3rd session of the Commission on Sustainable Development. Economic and Social Council. Official records, Supplement No.12.

[3] Barro, R.J. (1991). Economic Growth in a Cross Section of Countries. The Quarterly Journal of Economics, 106 (2), 407-443.

[4] Chen, D. H.C. \& Dahlman, C.J. (2005). The Knowledge Economy-The KAM Methodology and World Bank Operations. World Bank Institute Working Paper No. 37256

[5] Cook, P., \& Leydesdorff, L. (2006):Regional Development in the Knowledge-Based Economy: The Construction of Advantage, Journal of Technology Transfer, 31(3), 5-15.

[6] Commission on Sustainable Development (1995). Conference. New York

[7] Djekic, S. \& Hafner, N. (2013). Savremeni koncept upravljanja institucionalnom dimenzijom odrzivog razvoja. Teme. [. XXXVII Vol. 3 p. 1243-1261. UDK 005.71:502.131.1

[8] Drucker, P. (1993). Post-capitalist society. Butterworth-Heinemann. Oxford

[9] ERAWATCH - Platform on research and Innovation policies and systems. (2013). European Commission

[10] European Commission, (2010). Retrieved from http://eurlex.europa.eu/LexUriServ/LexUriServ.do?uri=COM:2010:2020:FIN:EN:PDF

[11] Eurostat (2015) The Sustainable Development Indicators.

[12] Goodland, R. \& Ledec, G. (1987). Neoclassical economics and principles of sustainable development. Ecological Modelling 38, 19-46.

[13] Gorghiu, M, \& Petrescu A.M.(2014). The Social Knowledge - A Goal of the Social Sustainable Development, Procedia-Social and Behavioral Sciences, 149, 43-49.

[14] Hawkes, J. (2001). The fourth pillar of sustainability - Culture`s essential role in public planning, Cultural Development Network

[15] Henning, C. (2008). Criticisms of the Neo-Classical Development Model. ECON 4999. Retrieved from http://www.colorado.edu/economics/morey/4999Ethics/essays/StudentEssays/4999HenningEs say1_CriticismNeoclassDevModel.pdf

[16] Huggins R.A., \& Izushi H. (2008) Competing for Knowledge: Creating, Connecting and Growing. Routledge

[17] Jednak, S., \& Kragulj, D. (2010). Knowledge based economy - the base of economic growth and development. Management, 15(15), 5-13.

[18] Jones, C.I. (1995). R\&D-Based Models of Economic Growth. The Journal of Political Economy. 103 (4), 759-784.

[19] Kragulj, D. (2014). Ekonomija - osnovi mikroekonomske i makroekonomske analize. Beograd.

[20] Lapinskiene, G. (2011). The analysis of the Relationship between the Sustainable Development and Competitiveness in the European Countries. Intelektine ekonomika - Intellectual Economics. 5 (3-11) 
[21] Lucas, R.E. (1988). On the mechanics of economic development, Journal of Monetary Economics, 22(1), 3-42.

[22] Melnikas, B. (2010). Creating knowledge-based society and knowledge economy: the main principles and phenomena. Ekonomika. 89(2).

[23] National Sustainable Development Strategy (NSDS) of the Republic of Serbia 2008

[24] Nonanko, I., \& Takeuchi, H. (1995). The knowledge-crating company: How Japanese companies create the dynamics of innovation. Oxford University Press

[25] OECD , (1996) The Knowledge-Based Economy.Paris. OECD/GD(96)102, 3- 9.

[26] Pearce, D. \& Atkinson, G. (1998). The Concept of sustainable development: An Evaluation of its Usefulness ten years after Brundtland. CSERGE Working Paper PA 98-02

[27] Pesic, R. (2002). Prirodni resursi i ekonomsko okruženje. Poglavlje : Odrzivi razvoj. Retrieved from http://www.policy.hu/pesic/GLAVA 1.pdf

[28] Piech, K. (2004). The Knowledge-Based Economy in Central and East European Countries - a review of some research results and policies.

[29] Pokrajac, S. (2009).Odrzivi razvoj i ekoloska ekonomija kao poslovne paradigme. Skola biznisa. UCD 502.131.1.

[30] Powell, W. W., Snellman, K. (2004). The Knowledge Economy, Annual Review of Sociology. 2004. 30, 199-220.

[31] Romeiro A.R. (2012). Sustainable development: an ecological economics perspective. Estudos Avancados 26(74).

[32] Romer P. (1986). Increasing Returns and Long-Run Growth, journal of political economy, 94 (5), p.1002-107

[33] Romer, P. M. (1994). "The Origins of Endogenous Growth". The Journal of Economic Perspectives 8 (1): 3-22. :

[34] Rostow, W.W. (1960). The Stages of Economic Growth: A Non-Communist Manifesto. Cambridge Univeristy Press

[35] Rudawska E., Renko S., Bilan Y. (2013). Sustainable development: concept, interest groups, benefits and global challenges. International Journal of Academic Research Part B, 5(6), 83-86. DOI: 10.7813/2075-4124.2013/5-6/B.15

[36] Sabau, G.L. (2010). Know, live and let live: Towards a redefinition of the knowledge-based economysustainable development nexus. Ecological Economics 69.

[37] Schumpeter, J.A. (1982). The Theory of Economic Development: an Inquiry Into Profits, Capital, Credit, Interest, and the business cycle. Transaction Publisher

[38] Solow, R. (1956). A contribution to the theory of economic growth, Quarterly Journal of Economics, 70(1), 65-94.

[39] Solow, R.M. (1991). Sustainability: An Economist's Perspectiv. in Dorfman, R. and Dorfman, N. (1993) Economics of the Environment: Selected Readings $3^{\text {rd }}$ ed. New York, W.W. Norton

[40] Statistical Office of the Republic of Serbia. (2013). Material Flow indicators for the Republic of Serbia 2001-2011. ISBN 978-86-6161-064-6

[41] Steurer, R. \& Berger, G. (2010). The Lisbon Strategy and sustainable development strategies across Europe: How different governance arrangements shape the European coherence of policy documents. Institute of Forest, Environmental, and Natural Resource Policy. University of Natural Resources and Applied Life Sciences, Vienna (BOKU)

[42] The Europe 2020 Competitiveness Report. 2014.

[43] The Report on the Progress in Realisation of Sustainable Development National Strategy for the period 2009-2017

[44] The World Economic Forum Report 2014-2015

[45] UNESCO Universal Declaration on Cultural Diversity (2002). The Records of the 31st session of the General Conference, UN Educational, Scientific and Cultural Organization.

[46] Vivien, F.D. (2008). Sustainable development: An overview of economic proposals. S.A.P.I.EN.S. vol.1, no.2. 1193-1201

[47] Vodic kroz strategiju Evropa 2020. Evropski pokret Srbije. Fond za otvoreno drustvo Srbije.

[48] WEF, (2014). The Europe 2020 Competitiveness Report - Building a more competitive Europe. World Economic Forum

[49] WCED - World Commission on Environment and Development, (1987). the Brundtland Commission`s Report: Our Common Future. 


\section{$1 / 1 / 1 / 1 / 1 / 1 / 1 / 1 / 1 / 1 / 1 / 1 / 1 / 1 / 1 /$ abouthe enturor}

\section{Sandra Jednak \\ University of Belgrade, Faculty of Organizational Sciences sjednak@fon.bg.ac.rs}

Sandra Jednak is employed at the Faculty of Organizational Sciences, University of Belgrade as an assistant professor. She has published numerous scientific research papers in international and national monographs, journals and conference proceedings. Her teaching areas are Introduction to Economics, Macroeconomics, Microeconomics, Economic Development and the EU. Her research focus is on the economic growth and development of SEE countries. Besides, her research interests are Economics of ICT, Knowledge (Based) Economy, Energy Economics, International Economics and Higher Education.

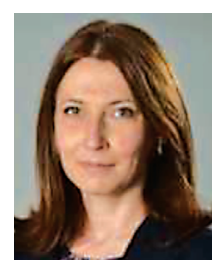

Dragana Kragulj University of Belgrade, Faculty of Organizational Sciences kragulj@fon.bg.ac.rs

Dragana Kragulj, Ph.D., is a full professor at the Faculty of Organizational Sciences,

University of Belgrade. She was a Chair of the Department of Economics, Business Planning and International Management. She has published several editions of different textbooks on Economics, two monographs of her own and over 100 scientific papers published in reputable national and international journals and conferences. She has been involved in several research projects. In addition to her teaching, she is occupied with research of macroeconomic problems, prices, market, inflation, economic development, investment, international trade, agriculture, energy economics, process of transition, international economic integrations, the European Union. 